\title{
PENILAIAN KERENTANAN LAHAN SAWAH PADI TERHADAP BANJIR DAS CIDURIAN DI DESA RENGED, KECAMATAN BINUANG, SERANG, BANTEN
}

\section{VULNERABILITY ASSESSMENT OF PADDY FIELD TO THE FLOOD HAZARD CIDURIAN WATERSHED IN RENGED VILLAGE, BINUANG DISTRIC, SERANG REGENCY, BANTEN PROVINCE}

\author{
Siti Dahlia1, Sudibyakto ${ }^{2}$ dan Dyah R. Hizbaron ${ }^{3}$ \\ ${ }^{1}$ Mahasiswa Sekolah Pascasarjana Universitas Gadjah Mada, Yogyakarta \\ ${ }^{2}$ Fakultas Geografi, Unversitas Gadjah Mada, Yogyakarta \\ ${ }^{3}$ Fakultas Geografi, Unversitas Gadjah Mada, Yogyakarta \\ e-mail: dahliasiti51@yahoo.com
}

\begin{abstract}
Renged Village, Binuang District, Serang Regency, Banten Province is area which economic condition are influenced by agriculture sector, especially in paddy field. The major floods event in the last 21 years occurred in 1994, 2001, and 2013, that caused harvest failure for farmer. The aims of research: (1) flood hazard analysis based on historical data of flood 1994, 2001, and 2013, and (2) vulnerability assessment of paddy field to the flood hazard Cidurian Watershed. Research conducted using qualitative and quantitative methods, with landform and community perception approach. The data analysis are interpolation, scoring, and weighting scenario. The result of the research shows that most of research area located in medium level of flood hazard. The high level of flood hazard is distributed in landform units: flood plain, abandoned river channels, and aluvial plain that associated with irrigation drainage. The result of vulnerability assessment shows that the highest of vulnerability index of paddy field using equal weight scenario, with index from 0 to 0.89 . The lowest of vulnerability index of paddy field using crop phase weight scenario, with index from 0 to 0.77 . The high level vulnerability of paddy field is distributed in landform units: flood plain and aluvial plain that associated with irrigation drainage.
\end{abstract}

Keywords: Vulnerability Assessment, Flood Hazard, Cidurian Watershed, Paddy Field, Landform, Perception.

\begin{abstract}
ABSTRAK
Desa Renged Kecamatan Binuang Kabupaten Serang Provinsi Banten, merupakan daerah yang kondisi ekonominya sebagian besar dipengaruhi oleh sektor pertanian yaitu padi sawah. Peristiwa banjir besar dalam 21 tahun terakhir terjadi pada tahun 1994, 2001, dan 2013, yang mengakibatkan gagal panen bagi petani. Tujuan penelitian ini yaitu: (1) menganalisis bahaya banjir daerah penelitian berdasarkan data kejadian banjir tahun 1994, 2001, dan 2013, dan (2) menilai tingkat kerentanan lahan sawah padi terhadap bahaya banjir. Penelitian ini dianalisis secara kualitatif dan kuantitatif, dengan menggunakan pendekatan bentuklahan dan persepsi masyarakat. Metode analisis data yang digunakan yaitu metode interpolasi, skoring, dan skenario pembobotan. Hasil penelitian menunjukkan bahwa sebagian besar wilayah penelitian berada pada kelas bahaya banjir sedang. Bahaya banjir kelas tinggi wilayah penelitian terdapat pada satuan bentuklahan dataran banjir, aliran sungai mati, dan dataran aluvial yang berasosiasi dengan saluran irigasi. Hasil penilaian kerentanan menunjukkan bahwa nilai indeks kerentanan lahan sawah padi tertinggi terdapat pada skenario pembobotan seimbang (equal) dengan nilai indeks 0-0,89. Nilai indeks kerentanan lahan sawah padi terendah pada
\end{abstract}


skenario fase tanaman dengan nilai indeks $0-0,77$. Tingkat kerentanan tertinggi terdapat pada lahan sawah yang berlokasi di satuan bentuklahan: dataran banjir dan dataran aluvial.

Kata kunci: Penilaian Kerentanan, Bahaya Banjir, DAS Cidurian, Lahan Sawah Padi, Bentuklahan, Persepsi.

\section{PENDAHULUAN}

Indonesia merupakan negara yang rawan berbagai bencana alam, seperti kekeringan, banjir, tanah longsor, letusan gunung berapi, bencana gempa bumi, dan tsunami. Bencana banjir meskipun menimbulkan risiko relatif lebih rendah dibandingkan bencana letusan gunung berapi, gempa bumi atau tsunami, tetapi mempunyai frekuensi relatif lebih tinggi. Berdasarkan hal tersebut, apabila diakumulasikan bencana banjir dapat berpotensi menimbulkan kerugian yang sama besarnya dari ketiga bencana tersebut (Zubaidah et al., 2005). Ancaman banjir juga semakin sering berdampak pada lahan sawah, yang merupakan salah satu dampak dari perubahan iklim terhadap sektor pertanian. Peristiwa ini menyebabkan berkurangnya luas area panen, dan turunnya produksi padi secara signifikan (Badan Litbang Pertanian, 2011).

Penelitian ini mengkaji terkait kerentanan lahan sawah padi terhadap banjir DAS Cidurian di Desa Renged Kecamatan Binuang, Kabupaten Serang, Provinsi Banten. Desa Renged dipilih sebagai lokasi wilayah penelitian, karena dua faktor yaitu kondisi ekonomi penduduk dan lokasi geografis wilayah penelitian. Sebagian besar penggunaan lahan wilayah penelitian dimanfaatkan untuk lahan sawah, yaitu seluas 380,01 ha dari 474,76 ha luas total. Kondisi tersebut mengakibatkan sebagian besar penduduk setempat bekerja sebagai petani yaitu $60 \%$ atau 1966 penduduk, sehingga kondisi ekonomi wilayah penelitian dipengaruhi oleh sektor pertanian yaitu padi sawah. Secara geografis wilayah penelitian terletak di bagian hilir DAS Cidurian (Gambar 1a), dan kemiringan yang relatif datar sampai hampir datar yaitu 0-2 \%. Kondisi tersebut mengakibatkan wilayah penelitian rawan terhadap banjir luapan DAS Cidurian, termasuk lahan pertanian wilayah penelitian.

Hasil wawancara dengan masyarakat setempat menunjukkan bahwa banjir di wilayah penelitian terjadi setiap tahun. Peristiwa banjir besar yang mengakibatkan gagal tanam dan panen bagi petani, dalam 21 tahun terakhir terjadi pada tahun 1994, 2001, dan 2013. Berdasarkan hal tersebut, lahan sawah padi Desa Renged memiliki ancaman tinggi terhadap banjir DAS Cidurian.
Kajian penilaian kerentanan berdasarkan analisis bahaya dan analisis kerentanan dengan elemen berisiko terfokus pada lahan sawah padi. Bahaya banjir yaitu probabilitas terjadinya peristiwa banjir yang berpotensi merusak, pada besaran (magnitude) dan di daerah tertentu dalam jangka waktu tertentu (Dang et al., 2010). Kerentanan dalam konteks penelitian ini yaitu derajat potensi kerugian atau kerusakan terhadap elemen yang berisiko yang merupakan akibat dari terjadinya fenomena alam, tingkat kerentanan dan kerusakan elemen berisiko diberi nilai 0 jika tidak ada kerusakan dan nilai 1 jika kerusakan total (Thywissen, 2006).

Penilaian kerentanan lahan sawah padi dalam penelitian ini menggunakan pendekatan bentuklahan dan persepsi masyarakat. Pendekatan bentuklahan digunakan karena kajian geomorfologikal untuk tujuan hidrologikal harus menekankan pada peranan bentuklahan dan faktor geomorfologikal lainnya (Verstappen, 2014). Selain itu, karakteristik geomorfologi menjadi kunci dalam kajian potensi banjir, banjir genangan ataupun jejak-jejaknya dapat dikenali dari pola bentuklahan pada dataran rendah (Setiawan et al., 2014). Pendekatan bentuklahan yang digunakan dalam penelitian ini yaitu bentuklahan asal proses fluvial, karena wilayah penelitian terbentuk oleh aktivitas Sungai Cidurian. Pendekatan persepsi masyarakat digunakan karena persepsi dan partisipasi masyarakat, secara langsung dapat membangun kesadaran dan kewaspadaan dalam menghadapi bahaya dan kerentanan (Irawan, 2015). Selain itu, informasi masyarakat lokal terkait bahaya merupakan penting, karena penduduk setempat memiliki pengetahuan tentang peristiwa bahaya yang mereka alami (van Westen et al., 2011).

Berdasarkan hal tersebut tujuan dalam penelitian ini yaitu: (1) menganalisis bahaya banjir daerah penelitian berdasarkan data kejadian banjir tahun 1994, 2001, dan 2013, dan (2) menilai tingkat kerentanan lahan sawah padi terhadap bahaya banjir. Pertanyaan penelitian dalam penelitian ini yaitu: (1) Bagaimana kedalaman, durasi, dan frekuensi bahaya banjir, berdasarkan persepsi masyarakat?, dan (2) Bagaimana tingkat kerentanan lahan sawah padi terhadap bahaya banjir?. 


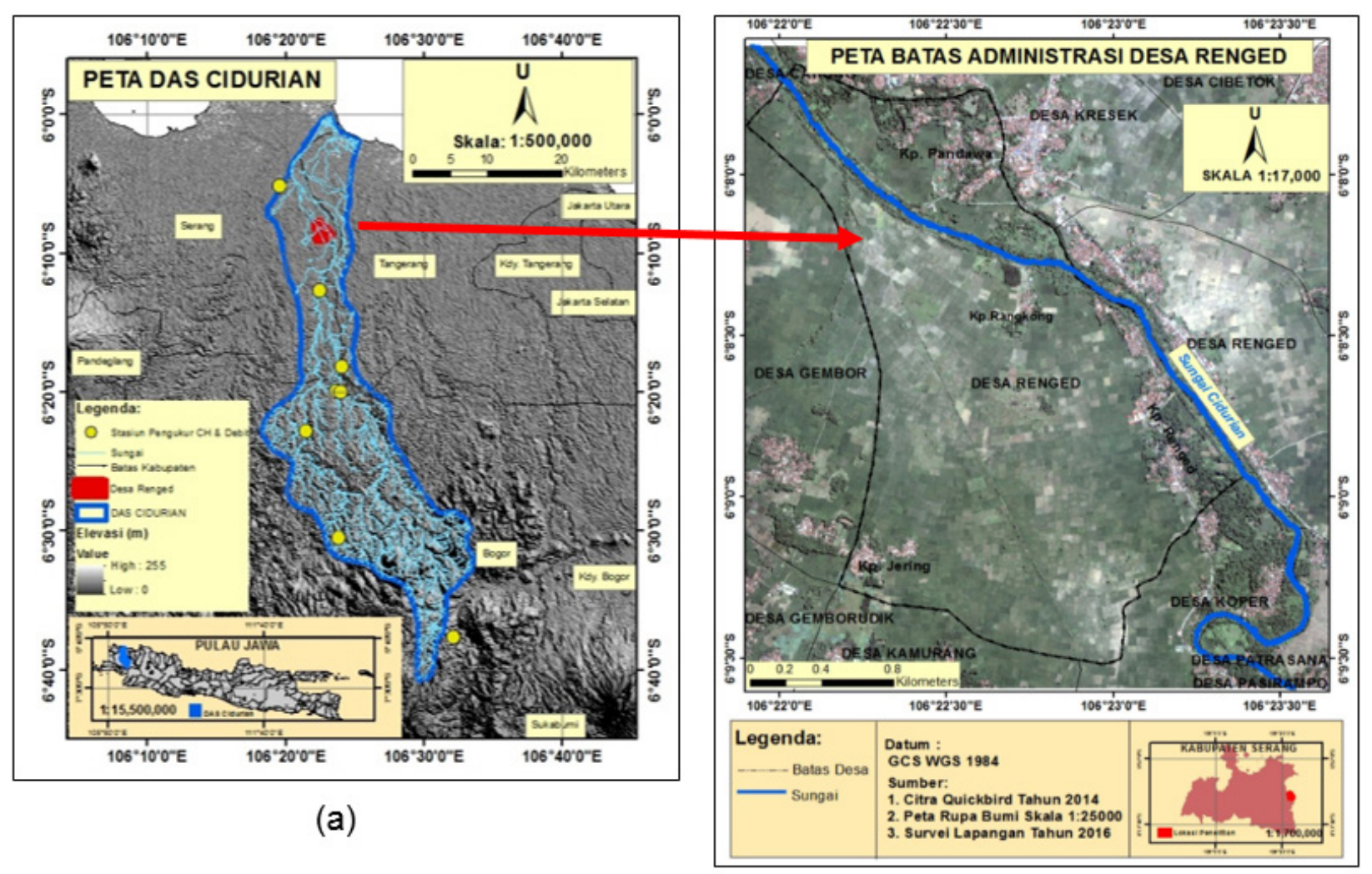

(b)

Gambar 1. Lokasi Penelitian (a) DAS Cidurian, (b) Batas Administrasi Desa Renged

\section{METODE PENELITIAN}

\subsection{Waktu dan Lokasi Penelitian}

Penelitian dilakukan pada musim penghujan yaitu bulan Januari Tahun 2016. Fokus pada lokasi Desa Renged, Kecamatan Binuang, Kabupaten Serang, Provinsi Banten. Secara astronomis terletak pada $6^{\circ} 7^{\prime} 51,239^{\prime \prime}$ LS - 6 $9^{\circ} 16,698^{\prime \prime}$ LS, dan $106^{\circ} 22^{\prime} 07,125^{\prime \prime}$ BT - $106^{\circ} 23^{\prime 2} 25,505^{\prime \prime}$ BT (Gambar 1b). Luas wilayah penelitian yaitu 474,76 ha.

\subsection{Bahan dan Data}

Bahan dan data yang digunakan dalam penelitian dapat dilihat pada Tabel 1.

Tabel 1. Bahan dan Data Penelitian

\begin{tabular}{|l|l|l|}
\hline No & \multicolumn{1}{|c|}{ Bahan dan Data } & \multicolumn{1}{c|}{ Sumber } \\
\hline 1 & $\begin{array}{l}\text { Karakteristik Banjir } \\
\text { (kedalaman, durasi, } \\
\text { dan frekuensi banjir) }\end{array}$ & $\begin{array}{l}\text { Wawancara dan } \\
\text { survei }\end{array}$ \\
\hline 2 & $\begin{array}{l}\text { Karakteristik Lahan } \\
\text { Sawah Padi }\end{array}$ & $\begin{array}{l}\text { Wawancara dan } \\
\text { survei }\end{array}$ \\
\hline 3 & $\begin{array}{l}\text { Peta RBI skala } \\
1: 25.000 \text { lembar No. } \\
\text { 1109-642 Tahun 1999 }\end{array}$ & BAKOSURTANAL \\
\hline
\end{tabular}

\begin{tabular}{|l|l|l|}
\hline 4 & $\begin{array}{l}\text { Citra Quickbird Tahun } \\
2014\end{array}$ & Google Earth \\
\hline 5 & $\begin{array}{l}\text { DEM TerraSAR Tahun } \\
2011\end{array}$ & $\begin{array}{l}\text { Badan Informasi } \\
\text { Geospasial }\end{array}$ \\
\hline
\end{tabular}

\subsection{Analisis Data}

Metode analisis penelitian yang digunakan yaitu kualitatif dan kuantitatif, dengan menekankan analisis pada pendekatan bentuklahan dan persepsi masyarakat. Pendekatan bentuklahan dalam penelitian, terfokus pada bentuklahan fluvial. Pendekatan persepsi masyarakat dalam konteks penelitian ini merupakan tidak murni secara kualitatif, karena menggunakan pengetahuan dan pengalaman petani melalui wawancara terkait karakteristik banjir dan informasi lahan sawah padi untuk kuantifikasi variabel bahaya banjir, dan kerentanan.

Populasi dalam penelitian ini yaitu petani pemilik lahan sawah padi di Desa Renged, yang meliputi petani hak milik dan hak garap. Metode penentuan sampel responden yang digunakan yaitu purposive sampling. Jumlah total responden yang diperoleh yaitu 119 responden, dan teknik pengumpulan data yang digunakan yaitu wawancara mendalam, kuesioner, dan survei. 
Analsisi bahaya banjir wilayah penelitian berdasarkan data persepsi masyarakat pada satuan bentuklahan fluvial, terkait kejadian banjir tahun 1994, 2001, dan 2013. Berdasarkan parameter kedalaman, durasi, dan frekuensi banjir, dengan analisis data menggunakan metode skoring dan interpolasi Natural Neighbour. Analisis kerentanan lahan sawah padi wilayah penelitian berdasarkan pendekatan indikator (Cutter et al., 2000; Deressa et al., 2008). Indikator yang digunakan yaitu fase pertumbuhan tanaman padi, produktivitas, luasan lahan sawah, dan jarak lahan sawah dari sungai (Tabel.2). Unit analisis yang digunakan untuk penilaian kerentanan, yaitu persil lahan sawah. Metode penilaian kerentanan menggunakan skoring dan skenario pembobotan (Tabel.3). Skala yang digunakan untuk penilaian kerentanan yaitu skala 0-1, skala 0 menunjukkan tidak rentan dan 1 rentan secara keseluruhan.

Tabel 2. Analisis Data Indikator Kerentanan

\begin{tabular}{|c|l|l|}
\hline No & \multicolumn{1}{|c|}{ Indikator } & \multicolumn{1}{c|}{ Deskripsi } \\
\hline 1 & Fase tanaman & $\begin{array}{l}\text { Fase tanaman pada tahap kebutuhan air rendah, semakin tinggi tingkat } \\
\text { kerentanannya (+) }\end{array}$ \\
\hline 2 & Produktivitas & $\begin{array}{l}\text { Semakin tinggi hasil produktivitas lahan sawah padi pada persil lahan sawah, } \\
\text { maka semakin tinggi tingkat kerentanannya (+) }\end{array}$ \\
\hline 3 & Luasan Lahan Sawah & $\begin{array}{l}\text { Semakin luas lahan sawah per persil, semakin tinggi tingkat kerentanannya } \\
(+)\end{array}$ \\
\hline 4 & Jarak lahan dari sugai & $\begin{array}{l}\text { Semakin dekat jarak lahan sawah dengan sungai, semakin tinggi tingkat } \\
\text { kerentannannya }(+)\end{array}$ \\
\hline
\end{tabular}

Catatan; (+) memiliki kontribusi tinggi terhadap kerentanan.

Tabel 3. Skenario Pembobotan Kerentanan

\begin{tabular}{|l|c|c|c|c|c|}
\hline Skenario & Bahaya & $\begin{array}{c}\text { Fase } \\
\text { Tanaman }\end{array}$ & Produktivitas & $\begin{array}{c}\text { Luasan } \\
\text { Lahan }\end{array}$ & $\begin{array}{c}\text { Jarak Lahan dari } \\
\text { Sungai }\end{array}$ \\
\hline Bahaya & 0,40 & 0,15 & 0,15 & 0,15 & 0,15 \\
\hline Fase tanaman & 0,15 & 0,40 & 0,15 & 0,15 & 0,15 \\
\hline Produktivitas & 0,15 & 0,15 & 0,40 & 0,15 & 0,15 \\
\hline Luasan lahan & 0,15 & 0,15 & 0,15 & 0,40 & 0,15 \\
\hline Jarak lahan dari sungai & 0,15 & 0,15 & 0,15 & 0,15 & 0,40 \\
\hline Seimbang (Equal) & 0,20 & 0,20 & 0,20 & 0,20 & 0,20 \\
\hline
\end{tabular}

Sumber: Hizbaron et al., 2012 dengan modifikasi

\section{HASIL DAN PEMBAHASAN}

\subsection{Peta Satuan Bentuk Lahan Fluvial Wilayah Penelitian}

Wilayah penelitian merupakan daerah dataran rendah dan dilalui oleh aliran Sungai Cidurian, sehingga memiliki bentuklahan asal proses fluvial yang terdiri atas: aliran sungai mati $(7,56$ ha), dataran aluvial (351,83 ha), dataran banjir $(66,12$ ha), tanggul alam (21,97 ha), dan dataran aluvial antropogenik (27,29 ha) (Gambar 2). Satuan bentuklahan fluvial terluas wilayah penelitian yaitu dataran aluvial dengan luas 351,83 ha. Satuan bentuklahan fluvial wilayah penelitian di dominasi oleh dataran aluvial, yang merupakan hasil proses sedimentasi pada topografi datar dengan material aluvium. Kondisi tersebut dapat diidentifikasikan bahwa wilayah penelitian terpengaruh oleh aktivitas banjir dan penggenangan, karena material aluvium berasal dari hasil pengendapan ketika terjadi banjir dan penggenangan (Sunarto et al., 2014).

\subsection{Analisis Bahaya Banjir Wilayah Penelitian}

\subsubsection{Kedalaman Banjir}

Hasil peta interpolasi kedalaman banjir (Gambar 3), menunjukkan bahwa kedalaman banjir maksimum tahun 1994 dan 2013 yaitu 2,8 m, sedangkan tahun 2001 yaitu 3,8. Hasil interpolasi kedalaman banjir dari tiga tahun kejadian banjir besar, terdapat perbedaan pola spasial terkait kedalaman banjir. Peta dengan mayoritas warna biru terang sampai gelap (kedalaman banjir sedang sampai tinggi) didominasi pada tahun 2001 (Gambar 3b), dan 
warna gambar putih sampai biru terang (kedalaman banjir rendah sampai sedang) terdapat pada tahun 1994 (Gambar 3a). Kondisi tersebut menunjukkan bahwa pada tahun 2001, wilayah penelitian memiliki tingkat kedalaman banjir maksimum lebih tinggi dibandingkan banjir tahun 1994 dan 2013.

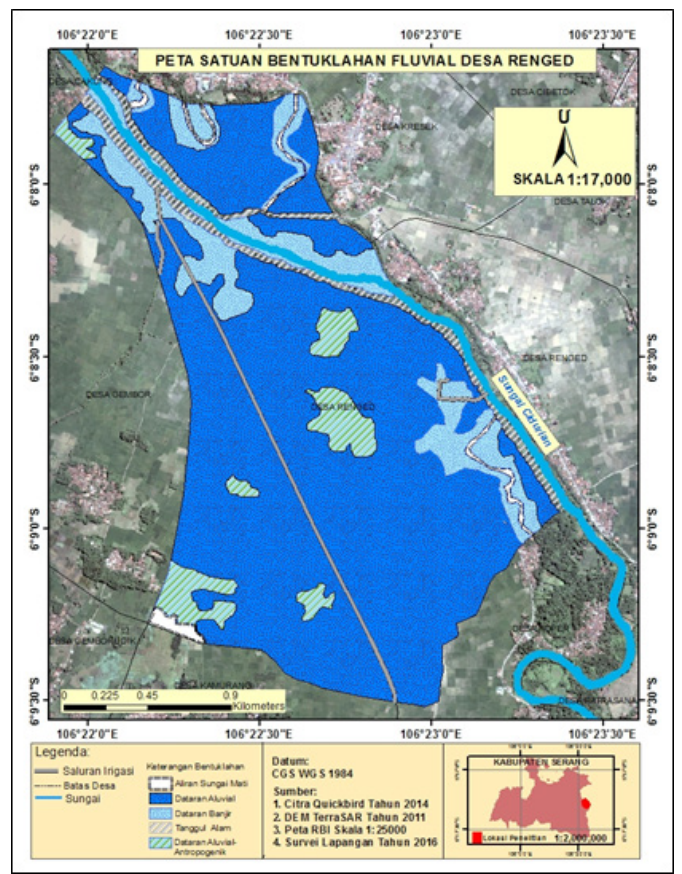

\section{Gambar 2. Peta Satuan Bentuk Lahan Fluvial Desa Renged}

Berdasarkan luasan, pada tahun 1994 sebagian besar wilayah penelitian berada pada tingkat kedalaman banjir sedang yaitu 0,5-1 m dengan
Iuas 202,43 ha. Pada tahun 2001, sebagian besar wilayah penelitian berada pada tingkat kedalaman banjir tinggi yaitu >1 m dengan luas 247,27 ha. Pada tahun 2013 sebagian besar wilayah penelitian memiliki tingkat kedalaman banjir sedang yaitu $0,5-$ $1 \mathrm{~m}$ dengan luas 199,62 ha (Gambar 4).

Berdasarkan kondisi tersebut pada tahun 2001 memiliki tingkat kedalaman banjir tinggi lebih luas, dibandingkan tahun 1994 dan 2013. Kondisi tersebut dapat diindikasikan pada tahun 2001, terjadi peningkatan volume banjir. Pada tahun 1994 lokasi dengan tingkat kedalaman banjir tinggi, lebih rendah dibandingkan tahun 2001 dan 2013. Berdasarkan hal tersebutdapatdiindikasikan bahwa terjadipeningkatan luasan dan kedalaman banjir setelah kejadian banjir tahun 1994. Kondisi peningkatan volume banjir, dapat diindikasikan salah satunya disebabkan oleh pengaruh perubahan iklim akibat pemanasan global dan perubahan penggunaan lahan (Dang et al., 2010; Marfai et al., 2014).

Berdasarkan distribusi spasial pada bentuklahan, hasil analisis menununjukkan bahwa pada tiga tahun kejadian banjir besar tersebut terdapat kesamaan terkait lokasi dengan tingkat kedalaman banjir tinggi (>1 m), yaitu pada satuan bentuklahan dataran banjir, aliran sungai mati, dan sebagian dataran aluvial. Tingkat kedalaman banjir sedang (0,5-1 $\mathrm{m})$ terdapat pada sebagian satuan bentuklahan dataran aluvial, dan tingkat kedalaman banjir rendah $(0-0,5 \mathrm{~m})$ yaitu pada satuan bentuklahan tanggul alam dan dataran aluvial antropogenik.

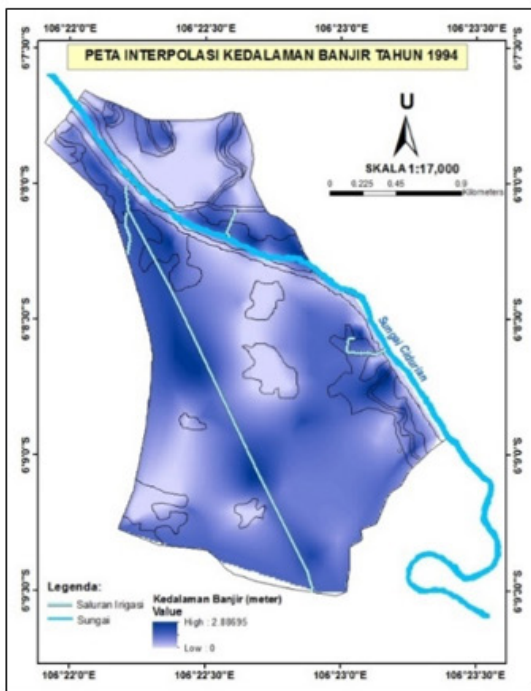

(a)

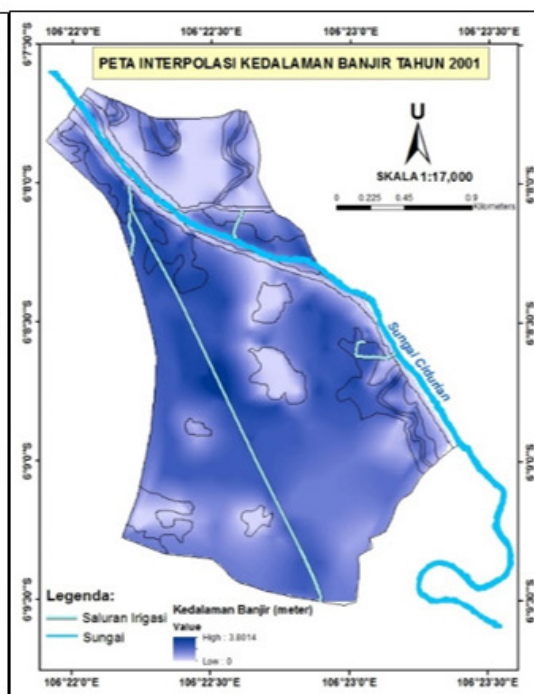

(b)

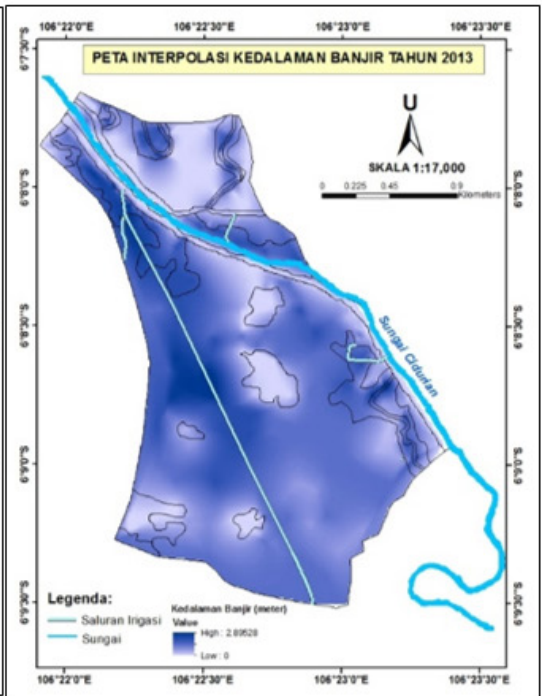

(c)

Gambar 3. Peta Interpolasi Kedalaman Banjir (a) Tahun 1994, (b) Tahun 2001, (c) Tahun 2013 


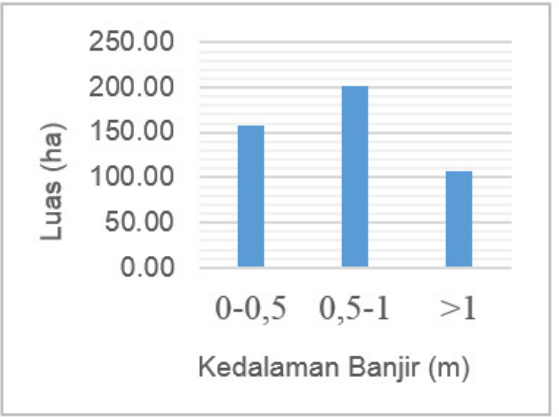

(a)

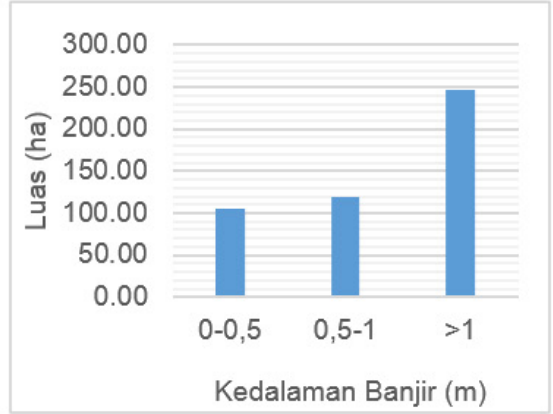

(b)

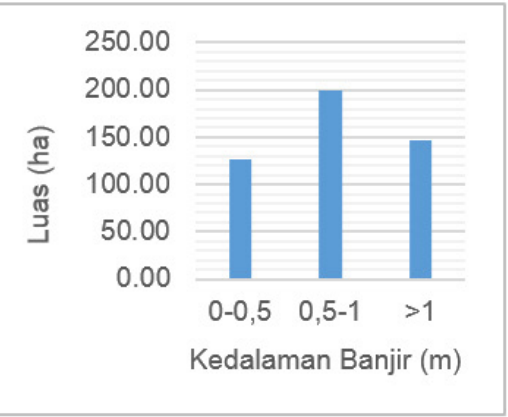

(c)

Gambar 4. Grafik Tingkat Kedalaman Banjir Wilayah Penelitian Berdasarkan Luasan, a) Tahun 1994, (b) Tahun 2001, (c) Tahun 2013

\subsubsection{Durasi Banjir}

Hasil peta interpolasi durasi banjir (Gambar 5), menunjukkan bahwa pada tiga tahun kejadian banjir besar tersebut memiliki pola spasial yang bervariasi. Pada tahun 1994 hasil interpolasi durasi banjir, sebagian besar wilayah penelitian memiliki durasi banjir sedang (warna kuning) dengan luas 239 ha. Pada tahun 2001 menunjukkan bahwa sebagian besar wilayah penelitian memiliki durasi banjir panjang $>10$ hari (warna merah), dengan luas 192,18 ha. Pada tahun 2013 sebagian besar wilayah penelitian memiliki durasi banjir sedang, yaitu 5-10 hari (warna kuning), dengan luas 218,82 ha (Gambar 6). Kondisi tersebut dapat diindikasikan dipengaruhi oleh pada tahun 2001 volume banjir lebih tinggi dibandingkan tahun 1994 dan 2013, sehingga dapat diasumsikan mempengaruhi panjangnya durasi banjir wilayah penelitian.
Berdasarkan distribusi spasial pada satuan bentuklahan, menunjukkan bahwa pada tiga tahun kejadian banjir besar tersebut daerah dengan durasi banjir panjang (>10 hari) yaitu terdistribusi pada satuan bentuklahan dataran banjir, aliran sungai mati, dan dataran aluvial yang berasosiasi dengan saluran irigasi. Durasi banjir sedang (5-10 hari) yaitu sebagian besar pada satuan bentuklahan dataran aluvial. Daerah dengan durasi pendek (0-5 hari) yaitu satuan bentuklahan tangul alam dan dataran aluvial antropogenik. Menurut Kundu (2010), faktor yang mempengaruhi panjangnya durasi banjir suatu wilayah yaitu faktor geomorfologi dan elevasi. Teori ini sesuai dengan kondisi wilayah penelitian, bahwa pada satuan bentuklahan aliran sungai mati, dataran banjir, dan dataran aluvial memiliki durasi banjir lebih panjang karena secara elevasi lebih rendah yaitu 2-14 m dpal dibandingkan dengan elevasi satuan bentuklahan dataran aluvial antropogenik dan tanggul alam yaitu 8-28 $\mathrm{m}$ dpal.

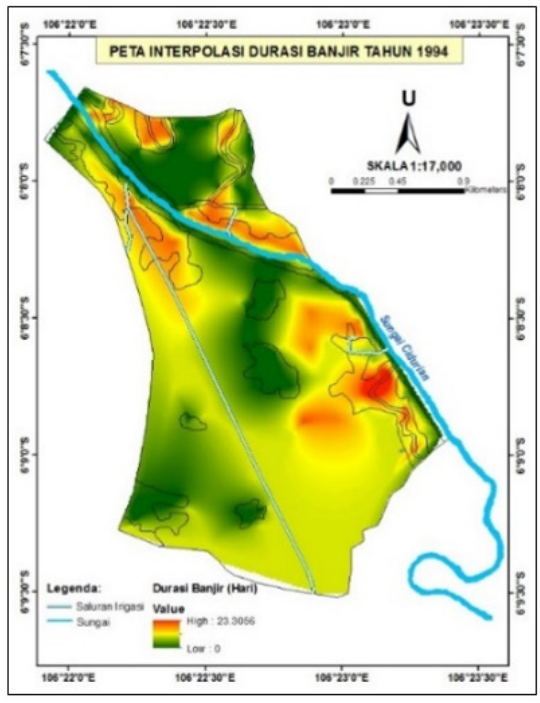

(a)

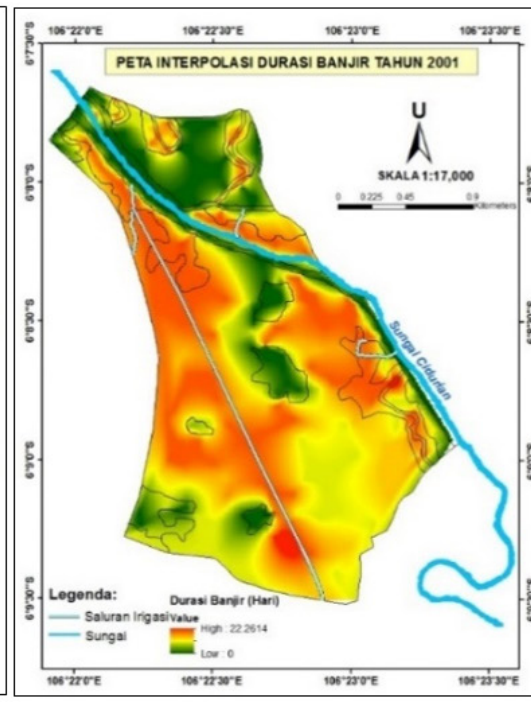

(b)

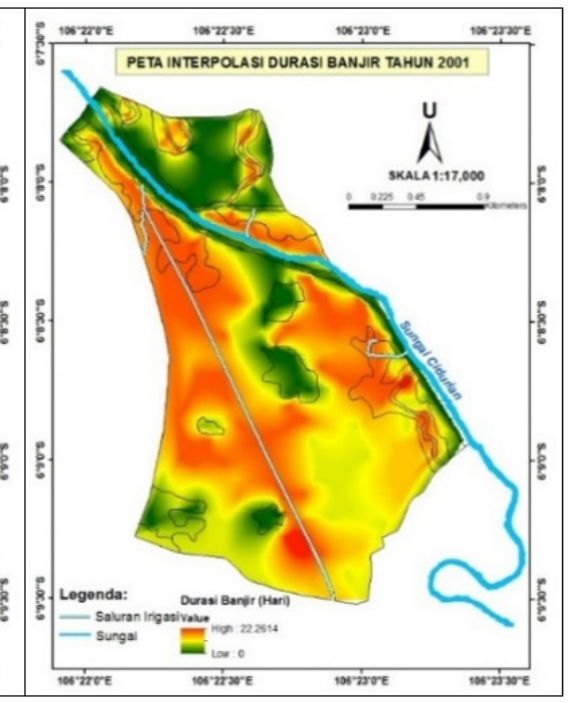

(c)

Gambar 5. Peta Interpolasi Durasi Banjir (a) Tahun 1994, (b) Tahun 2001, (c) Tahun 2013 


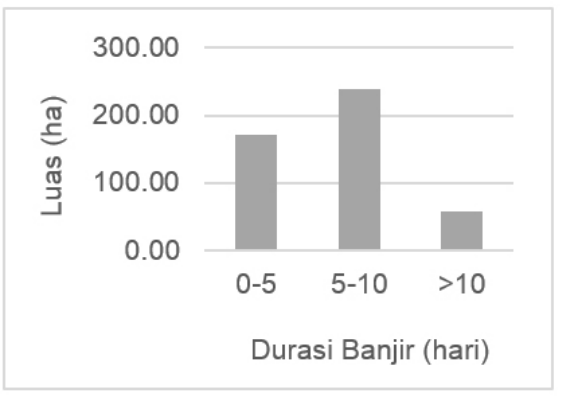

(a)

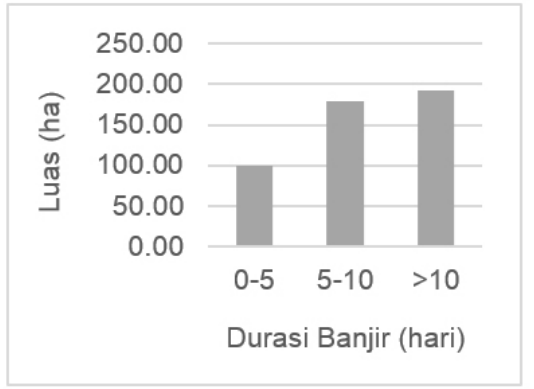

(b)

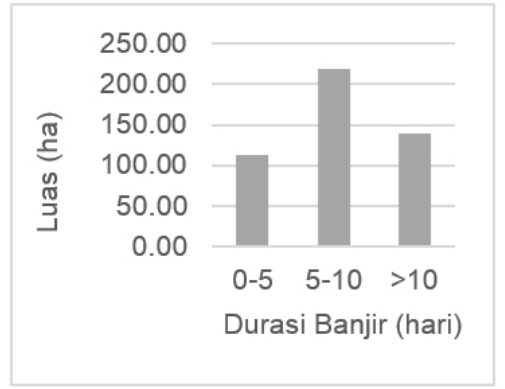

(c)

Gambar 6. Grafik Tingkat Durasi Banjir Wilayah Penelitian Berdasarkan Luasan, a) Tahun 1994, (b) Tahun 2001, (c) Tahun 2013

\subsubsection{Rata-Rata Kedalaman dan Durasi Banjir}

Hasil nilai kedalaman dan durasi banjir tahun 1994, 2001, dan 2013, dalam penelitian ini dilakukan perhitungan rata-rata, untuk identifikasi nilai rata-rata kedalaman dan durasi banjir dari tiga

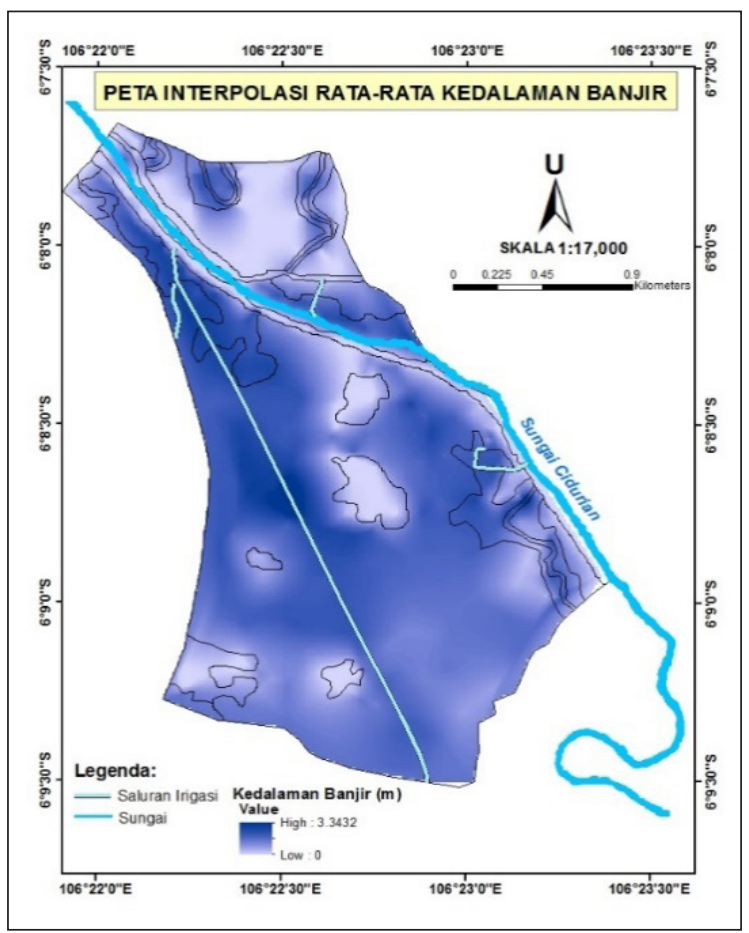

(a) tahun kejadian banjir besar. Hasil peta interpolasi nilai rata-rata kedalaman dan durasi banjir tahun 1994, 2001, dan 2013 wilayah penelitian, yaitu nilai kedalaman banjir maksimum 3,3 m (Gambar 7a), dan durasi banjir maksimum yaitu 21 hari (Gambar 7 b).

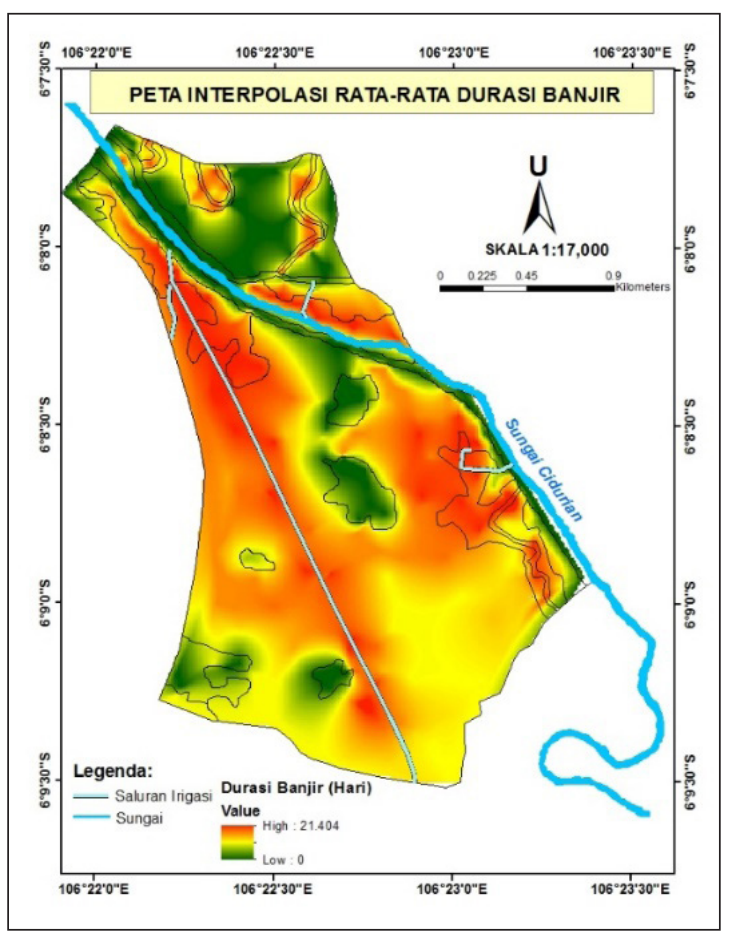

(b)

Gambar 7. Peta Interpolasi Rata-Rata (a) Kedalaman Banjir, dan (b) Durasi Banjir

\subsubsection{Frekuensi Banjir}

Analsis frekuensi banjir dilakukan secara kualitatif berdasarkan data historis, yaitu berdasarkan data jumlah kejadian banjir yang terjadi pada periode waktu tertentu. Berdasarkan hasil wawancara dengan responden terjadi 3 kali kejadian banjir besar dalam kurun waktu 21 tahun (1994-2015) di wilayah penelitian. Menurut Islam et al (2013), dalam penelitiannya menyatakan bahwa frekuensi banjir berdasarkan data historis apabila terjadi banjir satu kali setelah 2-5 tahun merupakan frekuensi sedang, dan satu kali setelah 10 tahun yaitu frekuensi rendah. Berdasarkan hal tersebut, frekuensi banjir wilayah penelitian dapat diasumsikan rata-rata termasuk pada kategori frekuensi rendah. Semakin rendah frekuensi kejadian banjir, maka semakin tinggi potensi magnitudo banjir (van Westen et al., 2011). 


\subsubsection{Peta Bahaya Banjir Wilayah Penelitian}

Hasil analisis peta bahaya banjir wilayah penelitian (Gambar 8a) ditinjau berdasarkan luasan, daerah dengan kelas bahaya banjir tinggi seluas 161,20 ha, sedang seluas 189,70 ha, dan rendah seluas 120,77 ha. Kondisi tersebut menunjukkan bahwa sebagian besar wilayah penelitian termasuk pada kelas bahaya banjir sedang. Faktor yang mempengaruhi kondisi tersebut dapat diindikasikan dipengaruhi oleh faktor kondisi geomorfologi, elevasi, dan tekstur tanah wilayah penelitian. Secara geomorfologi wilayah penelitian merupakan dataran rendah, dan terdapat satuan bentuklahan yang merupakan identitas rawan banjir yaitu aliran sungai mati, dataran banjir dan dataran aluvial (Setiawan et al., 2014). Berdasarkan elevasi sebagian besar wilayah penelitian memiliki elevasi rendah sampai sedang yaitu 2-14 m dpal (Gambar $8 b)$, sehingga menjadi tempat muara aliran sungai mati dan saluran irigasi yang berasal dari desa bagian selatan wilayah penelitian. Kondisi tersebut mengakibatkan wilayah penelitian menjadi tempat akumulasi air banjir Sungai Cidurian, yang mengalir dari Desa Koper dan Desa Gembor (Gambar 1b). Secara tekstur tanah, hasil analisis menunjukkan bahwa sebagian besar tekstur tanah wilayah penelitian merupakan berlempung. Kondisi tekstur tanah yang berlempung memiliki kemampuan infiltrasi yang lambat (Purnama dan Mudjiatun, 2014).

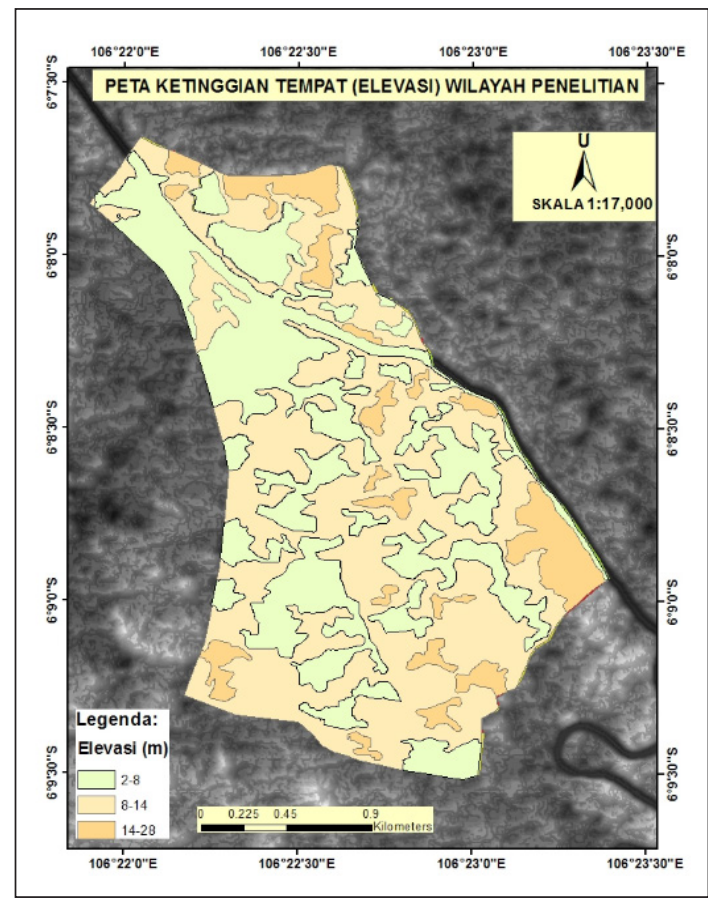

(a)
Berdasarkan distribusi spasial pada bentuklahan hasil analisis menunjukkan bahwa bahaya banjir wilayah penelitian dengan kategori kelas tinggi terdapat pada satuan bentuklahan dataran banjir yang berasosiasi dengan Sungai Cidurian, aliran sungai mati, dan dataran aluvial yang berasosiasi dengan saluran irigasi. Bahaya banjir dengan kategori sedang, terdapat pada satuan bentuklahan dataran banjir yang berasosiasi dengan aliran sungai mati, dan dataran aluvial. Bahaya banjir dengan kategori rendah terdapat pada satuan bentuklahan dataran aluvial antropogenik, tanggul alam, dan sebagian dataran aluvial. Satuan bentuklahan dataran banjir, aliran sungai mati, dan dataran aluvial merupakan satuan bentuklahan dengan kelas bahaya banjir tinggi, kondisi tersebut disebabkan oleh faktor pada satuan bentuklahan tersebut memiliki elevasi rata-rata 2-14 $\mathrm{m}$ dpal (rendah sampai sedang), dan berasosiasi dengan Sungai Cidurian serta saluran irigasi yang merupakan sumber banjir. Satuan bentuklahan dataran aluvial antropogenik dan tanggul alam merupakan kelas bahaya banjir rendah, karena memiliki elevasi yang lebih tinggi dibandingkan satuan bentuklahan lainnya yaitu 8-28 m dpal. Ditinjau berdasarkan penggunaan lahan daerah dengan kelas bahaya banjir tinggi sampai sedang, sebagian besar terdapat pada penggunaan lahan yaitu sawah.

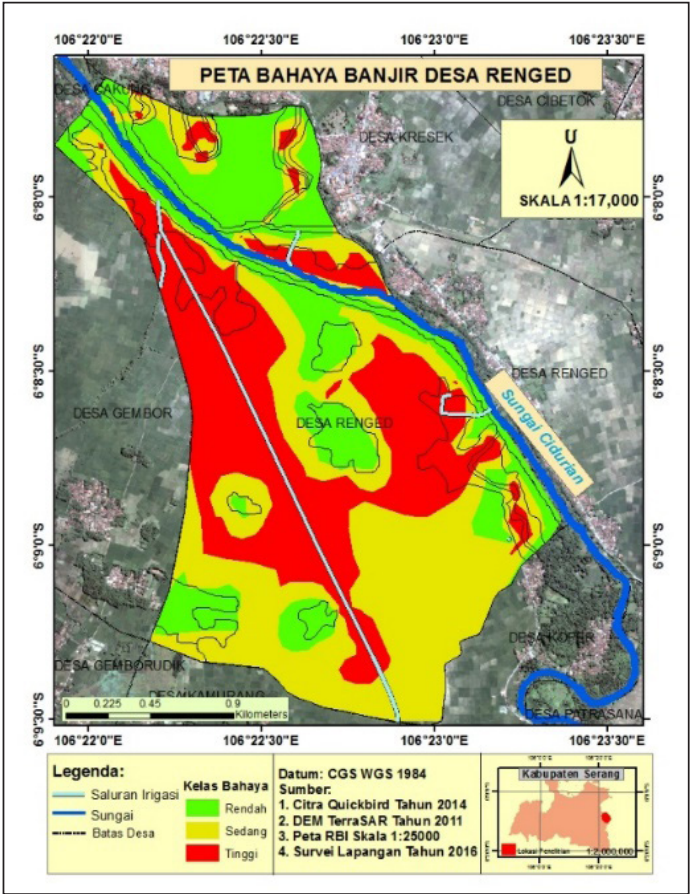

(b)

Gambar 8. (a) Peta Bahaya Banjir, (b) Peta Elevasi Wilayah Penelitian 


\subsection{Penilaian Kerentanan Lahan Sawah Padi Wilayah Penelitian}

Hasil perhitungan kerentanan menghasilkan nilai indeks dan peta kerentanan dengan enam skenario. Peta kerentanan dengan skenario memiliki manfaat untuk memperbanyak analisis prediksi, karena semakin banyak analisis prediksi dapat diindikasikan semakin mendekati kondisi di lapangan. Nilai indeks kerentanan dengan skenario dapat dilihat pada Tabel 4, 5, 6, 7, 8 dan 9 .

Tabel 4. Nilai Kerentanan Skenario Bahaya

\begin{tabular}{|c|c|c|}
\hline $\begin{array}{c}\text { Interval } \\
\text { Nilai Indeks }\end{array}$ & Kelas & $\begin{array}{c}\text { Jumlah Lahan } \\
\text { Sawah (Persil) }\end{array}$ \\
\hline $0,30-0,48$ & Rendah & 45 \\
\hline $0,49-0,67$ & Sedang & 64 \\
\hline $0,68-0,86$ & Tinggi & 74 \\
\hline
\end{tabular}

Tabel 5. Nilai Kerentanan Skenario Fase Tanaman

\begin{tabular}{|c|c|c|}
\hline $\begin{array}{c}\text { Interval } \\
\text { Nilai Indeks }\end{array}$ & Kelas & $\begin{array}{c}\text { Jumlah Lahan } \\
\text { Sawah (Persil) }\end{array}$ \\
\hline $0,30-0,45$ & Rendah & 62 \\
\hline $0,46-0,61$ & Sedang & 83 \\
\hline $0,62-0,77$ & Tinggi & 38 \\
\hline
\end{tabular}

Tabel 6. Nilai Kerentanan Skenario Produktivitas

\begin{tabular}{|c|c|c|}
\hline $\begin{array}{c}\text { Interval } \\
\text { Nilai Indeks }\end{array}$ & Kelas & $\begin{array}{c}\text { Jumlah Lahan } \\
\text { Sawah (Persil) }\end{array}$ \\
\hline $0,30-0,48$ & Rendah & 45 \\
\hline $0,49-0,67$ & Sedang & 88 \\
\hline $0,68-0,86$ & Tinggi & 50 \\
\hline
\end{tabular}

Tabel 7. Nilai Kerentanan Skenario Luasan Lahan Sawah

\begin{tabular}{|c|c|c|}
\hline $\begin{array}{c}\text { Interval } \\
\text { Nilai Indeks }\end{array}$ & Kelas & $\begin{array}{c}\text { Jumlah Lahan } \\
\text { Sawah (Persil) }\end{array}$ \\
\hline $0,30-0,48$ & Rendah & 64 \\
\hline $0,49-0,67$ & Sedang & 61 \\
\hline $0,68-0,86$ & Tinggi & 58 \\
\hline
\end{tabular}

Tabel 8. Nilai Kerentanan Skenario Jarak Lahan Sawah dari Sungai

\begin{tabular}{|c|c|c|}
\hline $\begin{array}{c}\text { Interval } \\
\text { Nilai Indeks }\end{array}$ & Kelas & $\begin{array}{c}\text { Jumlah Lahan } \\
\text { Sawah (Persil) }\end{array}$ \\
\hline $0,30-0,48$ & Rendah & 64 \\
\hline $0,49-0,67$ & Sedang & 61 \\
\hline $0,68-0,86$ & Tinggi & 58 \\
\hline
\end{tabular}

Tabel 9. Nilai Kerentanan Skenario Seimbang (Equal)

\begin{tabular}{|c|c|c|}
\hline $\begin{array}{c}\text { Interval } \\
\text { Nilai Indeks }\end{array}$ & Kelas & $\begin{array}{c}\text { Jumlah Lahan } \\
\text { Sawah (Persil) }\end{array}$ \\
\hline $0,30-0,49$ & Rendah & 38 \\
\hline $0,50-0,69$ & Sedang & 106 \\
\hline $0,70-0,89$ & Tinggi & 39 \\
\hline
\end{tabular}

Hasil penilaian kerentanan berdasarkan enam skenario pembobotan, menunjukkan bahwa nilai indeks kerentanan tertinggi terdapat pada skenario kerentanan bobot seimbang (equal), yaitu $0,30-0,89$ (Tabel. 9). Kondisi tersebut dapat diindikasikan pengaruh bobot setiap indikator yang seimbang yaitu 0,20 . Tinggi atau rendahnya nilai skor dan bobot diidentifikasi dapat mempengaruhi nilai kerentanan total. Jumlah lahan sawah dalam persil memiliki tingkat kerentanan tinggi terbanyak, terdapat pada skenario kerentanan bahaya yaitu 74 persil (Tabel.4). Kondisi tersebut menunjukkan bahwa hasil analisis penilaian kerentanan berdasarkan skenario, potensi kerugian atau kerusakan lahan sawah padi akibat banjir tertinggi terdapat pada skenario bahaya. Informasi ini dapat menjadi dasar arahan untuk direkomendasikan kepada pihak terkait pengurangan risiko bencana, terkait kemungkinan terburuk dampak dari kejadian banjir luapan Sungai Cidurian.

Hasil peta interpolasi kerentanan dengan enam skenario pembobotan (Gambar 9), menunjukkan bahwa terdapat pola spasial yang beragam. Berdasarkan distribusi spasial pada satuan bentuklahan, dari enam skenario terdapat kesamaan bahwa sebagian besar kelas kerentanan tinggi, terdapat pada lahan sawah yang berlokasi di dataran banjir dan dekat saluran irigasi. Selain itu, pada setiap skenario terdapat kesamaan pola spasial bahwa lahan sawah dengan tingkat kerentanan tinggi, sebagian besar terdapat pada lahan sawah dengan kelas bahaya banjir tinggi. Kondisi tersebut menunjukkan bahwa variabel bahaya memiliki kontribusi tinggi dalam mempengaruhi tingkat kerentanan lahan sawah padi wilayah penelitian. Analisis lebih lanjut bahwa adanya kesamaan pola spasial terkait lokasi tingkat kerentanan tinggi dari enam skenario hasil penilaian kerentanan, sebagai dasar argumen bahwa hasil penilaian dan analisis kerentanan lahan sawah padi wilayah penelitian merupakan valid. 


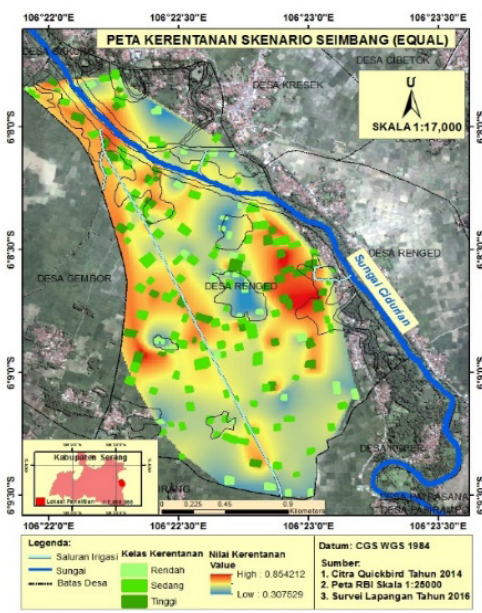

(a)

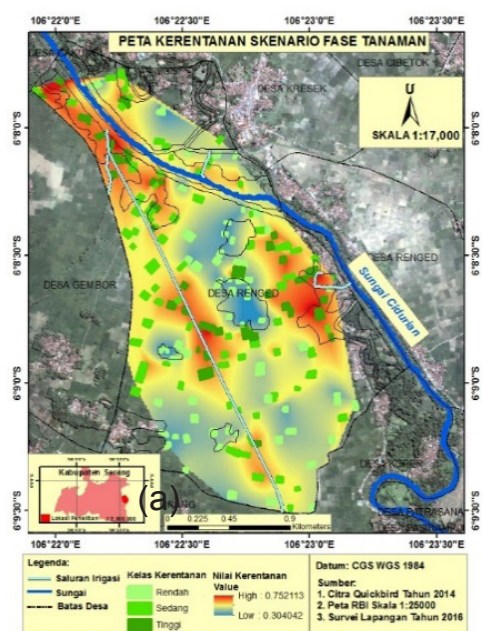

(a)

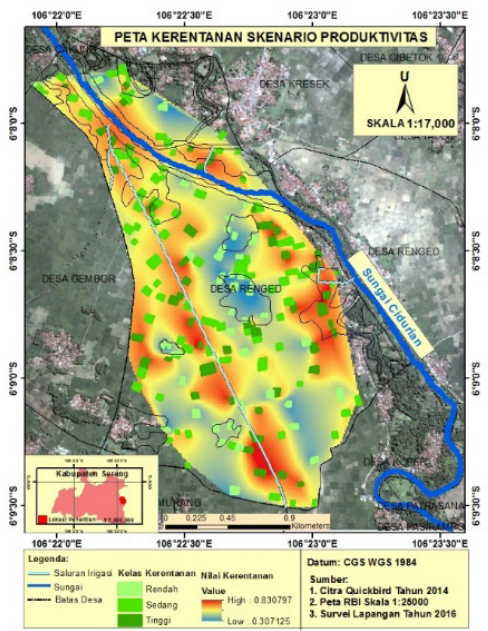

(b)

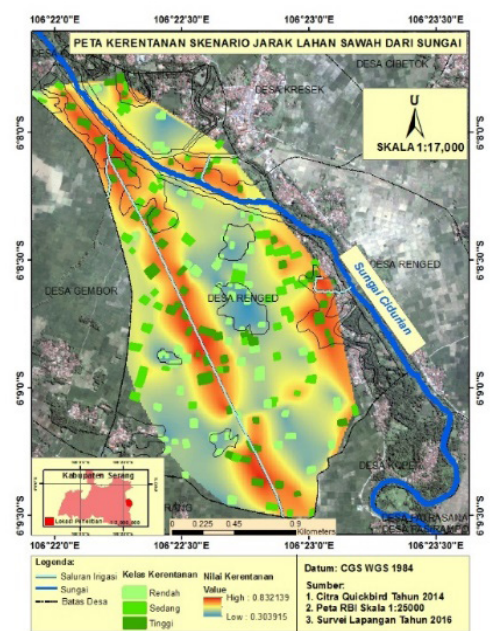

(b)

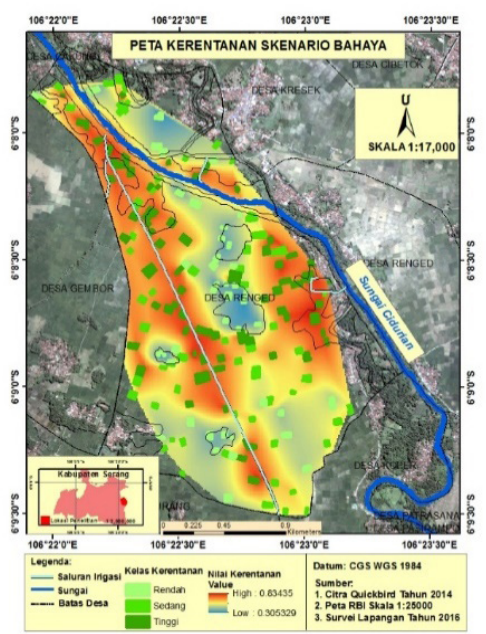

(c)

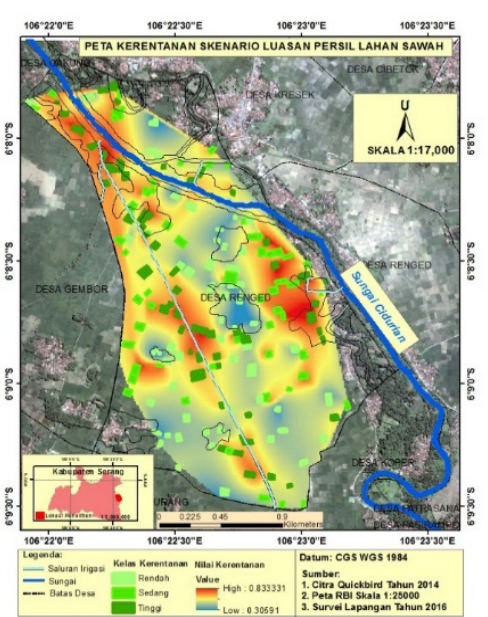

(c)

Gambar 9. Peta Skenario Kerentanan, (a) Skenario Bahaya, (b) Skenario Fase Tanaman, (c) Skenario Produktivitas, (d) Skenario Luasan Lahan (e) Skenario Jarak Lahan Sawah dari Sungai, dan (f) Skenario Seimbang (Equal)

\section{KESIMPULAN}

Penelitian ini terkait penilaian kerentanan lahan sawah padi terhadap banjir DAS Cidurian. Fokus pembahasan analisis yaitu analisis bahaya banjir DAS Cidurian terhadap wilayah penelitian berdasarkan data histori kejadian banjir besar tahun 1994, 2001, dan 2013, dan menilai kerentanan lahan sawah padi terhadap bahaya banjir. Hasil penelitian menunjukkan bahwa Wilayah penelitian sebagian besar terletak pada bahaya banjir kelas sedang seluas 189,70 ha. Kategori kelas bahaya banjir tinggi terdistribusi pada satuan bentuklahan dataran banjir, aliran sungai mati, dan dataran aluvial yang berasosiasi dengan saluran irigasi. Hasil analisis lebih lanjut menunjukkan bahwa faktor geomorfologi khususnya bentuklahan, saluran irigasi, elevasi, dan tekstur tanah dapat diidentifikasikan mempengaruhi tingkat bahaya banjir wilayah penelitian.

Hasil penilaian kerentanan dengan skenario bobot kerentanan menghasilkan indeks kerentanan lahan sawah tertinggi terdapat pada skenario seimbang (equal), dengan nilai indeks 0-0,89, dan terendah pada skenario fase tanaman dengan indeks kerentanan 0-0,77. Berdasarkan distribusi spasial pada satuan bentuklahan, terdapat kesamaan bahwa sebagian besar kelas kerentanan tinggi terdapat pada lahan sawah yang berlokasi di dataran banjir dan dekat saluran irigasi. 


\section{DAFTAR PUSTAKA}

Badan Litbang Pertanian, 2011, Pedoman Umum Adaptasi Perubahan Iklim Sektor Pertanian, Prosiding, <http:balittanah.litbang.pertanian. go.id/ind/index.php/publikasi-mainmenu-78/ pros/257-mfip> (diakses 19 Mei 2015).

Cutter, S.L., Mitchell, J.T., dan Scott, M.S., 2000, Revealing the vulnerability of people and places: A Case study of Georgetown County, South Carolina, Annals of the Association of American Geographers, 90(4), 713-737.

Dang, N.M., M.S. Babel. dan H.T. Luong., 2010, Evaluation of food risk parameters in the day river flood diversion area, Red River Delta, Vietnam, Journal of Natural Hazards 56:169-194.

Deressa, T., M., R. Hassan dan C. Ringler., 2008, Measuring Ethiopian farmers' vulnerability to climate change across regional states, Paper: International Food Policy Research Institute.

Hizbaron, D.R., M. Baiquni, J. Sartohadi dan R. Rijanta., 2012, Urban Vulnerability in Bantul District, Indonesia-Towards Safer and Sustainable Development, Sustainability: 4: 2022-2037; doi:10.3390/su4092022.

Irawan, L. Y. 2015. Kajian Persepsi dan Partisipasi Masyarakat dalam Pengurangan Risiko Banjir Lahar Gunungapi Kelud di Desa Pandansari, Kecamatan Ngantang, Kabupaten Malang. Thesis: Universitas Gadjah Mada.

Islam, M.N., M.A. Malak. dan M. Islam., 2013, Community-based disaster risk and vulnerability models of a coastal municipality in Bangladesh. Journal of Natural Hazards 69:2083.

Kundu, Sananda., 2010, Flood Characterisation and Inundation Pattern Mapping Using Radarsat Imagery for Rice Vulnerability Assessment, Thesis: International Institute for GeoInformation Science and Earth Observation dan Indian Institute Of Remote Sensing.

Marfai, M.A., B.S. Andung, dan W. Philip., 2014, Community responses and adaptation strategies toward flood hazard in Jakarta, Indonesia, Journal of Natural Hazards 75:1127 -1144.

Purnama, S., dan E. Mudjiatun., 2014, Aspek Air Tanah dalam Pengelolaan DAS, dalam Suprayogi., Purnama, dan Darmanto, 2014, Pengelolaan Daerah Aliran Sungai. Yogyakarta: Gadjah Mada University Press.
Setiawan, M.A., H. Warsin., dan Y. Sulistiyaningrum., 2014, Potensi Bencana Hidrometeorologi di Kawasan Sub-DAS Ampel, Kabupaten Jepara, dalam Sunarto., Marfai, M.A., dan M.A. Setiawan., 2014, Geomorfologi dan Dinamika Pesisir Jepara, Yogyakarta: Gadjah Mada University Press.

Sunarto., E. Rahayu, dan L. Nugrahaeni., Deskripsi Lingkungan Wilayah Pesisir Jepara, dalam Sunarto., M.A. Marfai. dan Setiawan, M.A., 2014, Geomorfologi dan Dinamika Pesisir Jepara, Yogyakarta: Gadjah Mada University Press.

Thywissen, Katherina., 2006, Core Terminology of Disaster Reduction: A Comparative Glossary dalam Measuring Vulnerability to Natural Hazards, Birkman, Jorn (editor), United Nations University Pess, Tokyo, hal: 448496.

Van Westen, C.J., D. Alkema, MCJ. Damen, N. Kerle, dan N.C. Kingma., 2011 Multi Hazard Risk Assessment, United Nations University - ITC School on Disaster Geoinformation Management.

Verstappen, H. Th., 2014, Garis Besar Geomorfologi Indonesia, Diterjemahkan oleh Sutikno, Editor Suratman, Yogyakarta: Gadjah Mada University Press.

Zubaidah, A., Suwarsono, dan R. Purwaningsih., 2005, Analisa daerah potensi banjir di Pulau Sumatera, Jawa dan Kalimantan menggunakan citra AVHRR/NOAA-16, Pertemuan IImiah Tahunan MAPIN XI. LAPAN, hal : 127.

\section{UCAPAN TERIMAKASIH}

Pada kesempatan ini penulis menyampaikan ucapan terimakasih kepada Sekolah Pascasarjana Universitas Gadjah Mada khususnya Program Minat Studi Geo-Infromasi untuk Manajemen Bencana atas kesempatanya kepada penulis untuk menuntut ilmu dalam kajian kebencanaan. Selanjutnya, kepada bapak Prof. Dr. H.A. Sudibyakto, M.S, dan ibu Dr. Dyah R. Hizbaron, M.T, M.Sc. selaku dosen pembimbing penelitian. 
